\title{
Capital Budgeting as a Tool of Management Decision Making: A Case Study of National Investment Bank Limited
}

\author{
AIKINS JUSTICE \\ University of Development Studies \\ EBENEZER NANA YEBOAH \\ School of Accounting and Finance, Zhongnan University of Economics and Law, Wuhan 430072, China. \\ OPOKU PIOUS \\ School of Accounting and Finance, Zhongnan University of Economics and Law, Wuhan 430072, China
}

\begin{abstract}
Sound financial management and decision-making on capital investments are critical to company survival and long-term success. With this truth affirmed by the global financial crisis, this study sets out to examine the capital budgeting tools at National Investment Bank Limited (NIB) in Ghana, adapted for management decision making. It establishes the various capital budgeting techniques used by NIB in undertaking investment projects and how these decisions affects the firm's value, profit and growth rate. As methodology, the study adopts both primary and secondary sources which are further analyzed with the use of correlation analysis. The findings reveal that there is a positive relationship between the variables and their effects are significant. The study concludes that, the firm used capital budgeting techniques such as Net Present Value, Internal Rate of Return, Profitability Index, Discounted Payback Period, Payback Period and Accounting Rate of Return in order to maximize the firm's value which is usually affected by the profit and the growth rate. Given the conclusion herein, the study recommends among others that NIB should educate and train their staff on the various capital budgeting tools and the formation of knowledgeable team that will evaluate projects using the capital budgeting tools due to its irreversibility nature, huge investment outlay and its long term effect.
\end{abstract}

Keywords: Capital budgeting, Techniques, Cash Flow, Investments, Decision making, Ghana

DOI: $10.7176 /$ RJFA/11-4-04

Publication date: February $29^{\text {th }} 2020$

\section{Introduction}

Capital planning is an organization's conventional procedure utilized for assessing potential uses or ventures that are critical in sum. Capital planning is a procedure that is worried about choices made by firms on long haul venture undertakings to accomplish the organizations in general objectives and goals (Dayananda et al, 2002). Management of firms normally make decisions that have financial significance and also helps in the achievement of the objective of the firms (maximizing the firm's value) which include the investment decision, financing decision and dividend decision. The achievement and disappointment of any association or undertaking for the most part relies upon the nature of its venture choice. It includes the choice like acquisition of fixed resources, for example, land and building, new hardware, remaking or supplanting existing gear, innovative work and some more. Organizations as a rule require huge measure of capital in embraced such ventures regularly alluded to as capital planning. In account, settling on these speculation choices is alluded to as capital planning (Megginson and Smart, 2009). The capital budgeting process includes the development, evaluation, study, selection and execution of longterm investment projects in accordance with the strategic objectives of the company (Megginson and Smart, 2009). First and foremost, a company must determine its corporate strategy; therefore, its large set of goals for future investments before taking into account capital budgeting (Peterson and Fabozzi, 2002). According to them, it is through long-term investment that the goal is to increase the wealth of shareholders and can help attain this corporate strategy.

The capital budgeting strategies used by management in their decision making include the non-discounted approach that does not consider money time value, and the discounted approaches that take care of money time value (Megginson and Smart, 2009). The non- discounted methods include Payback Period (PBP) and Accounting Rate of Return (ARR). Discounted method includes the Net Present Value (NPV), Internal Rate of Return (IRR), Discounted Payback Period (DPBP) and the Profitability Index (PI). Other things being equal, managers usually prefer the technique of capital budgeting which takes into account cash flow, time value of money, expected risk and return and leads to higher stock price (Megginson and Smart, 2009). Investment decisions have an important impact on the future cash flows of the firm and the risks associated with those cash flows. Capital budgeting decisions typically have a long-term impact on the operations of the company and are important to its success or failure (Dayananda et al, 2002). Economics is concerned with allocating limited resources between different users in order to achieve maximum satisfaction and attain the best goals. On the other hand, the distribution of these 
resources over time is concerned with capital budgeting; decisions involving initial outlays in exchange for expectations of future benefits, i.e. a return on an expected supply of future benefits (Jones, T. (2002). In this modern world, where companies face different competition from other local and international businesses, management seeks to extend their field of operation by taking on additional investment projects, expanding existing markets, acquiring new equipment in a bid to succeed, among others (Baker and English, 2011). All of these are considered as decisions to invest in management. The investment decisions that management takes into account when assessing the viability of all the identified opportunities and the future benefits of the project are referred to as decisions on capital budgeting.

With the objective to examine the capital budgeting tools used by National Investment Bank Ltd, this study explores on the critical role capital budgeting plays in making investment decisions in a bid to mitigate risk and uncertainties for the realization of business goals.

\section{Literature Review}

\subsection{Defining capital budgeting}

Pealver (2017) states that there are two words ' money ' and ' budget ' in capital budgeting. Capital is described as the funds used to finance the properties of a corporation (Peterson \& Fabozzi, 2002). Capital in this perspective is a long-term financial resource with life span of more than a year which is expected to generate future cash flows. The origins of these capital are, according to Megginson \& Smart (2009), internal accruals (depreciation and retained earnings), securities (equity stakes, preferred shares and bonds), term loans, advances in working capital and miscellaneous capital (lease and employ purchase). On the other hand, ' Budget ' is a projected revenue and expenditure for a given period of time, in particular the timeline for the project (Pealver, 2017). Capital budgeting is therefore the systematic steps taken to assess the long-term capital investment are worthwhile during the estimated time frame (Pealver, 2017). This process helps company management identify which investment with the capital invested will generate the highest returns possible. Capital budgeting deals with identifying and assessing long-term asset investments which are expected to generate cash flows for an organization (Peterson \& Fabozzi, 2002). Companies normally undertake long-term investment projects which require significant initial outlay or outflow. These outflows are normally invested in assets, also known as capital, and are repaid using the project-generated cash (inflows) (Peterson \& Fabozzi, 2002). These properties are divided mainly into two: tangible and intangible assets. Tangible assets include: ground, building, equipment, appliances, and fittings. Types of intangible assets are reputation, trademark, and reproduction rights (Peterson \& Fabozzi, 2002).

Capital budgeting has become one of the most challenging tasks for corporate management. It is concerned with investment decisions that deal with allocating resources to long-term projects in order to achieve the organization's goals (Baker \& English, 2011). Mostly, firms have different investment opportunities to pursue, but first they need to understand the company's overall goal, say, to maximize the value of the firm. Management then chooses the best investment to produce the highest returns, and will also help achieve the company's target. Thus in finance, the capital budgeting goal relies on the assumption that managers will concentrate on optimizing the market value of the firm in the course of managing the company's resources (Peterson \& Fabozzi, 2002).

\subsection{Capital budgeting processes}

There are lots of undertakings in the capital budgeting processes. The path features a number of consecutive cycles. There has to be a strategic business plan in place. Such strategies should consider the funding sources, where to spend such money, how much to pay as a dividend and how much to keep (Uwah \& Asuquo, 2016). Considering this capital budgeting undergoes a series of processes that may include identification and project proposal generation, project preliminary review, project financial evaluation, accept or reject decision, project implementation and tracking, and post-implementation audit.

\subsection{Capital Budgeting Evaluation Techniques and Risk}

Capital budgeting includes various processes or stages, including definition, evaluation, financial assessment, selection; capital project execution and analysis (Dayananda et al., 2002). Emphasis has been put on the review and selection stages of the capital budgeting processes in most finance literatures (Megginson and Smart, 2009). Many techniques are available for making capital investment choices. These techniques are grouped into two: Non- discounted method (Payback Period and Accounting Rate of Return) and the discounted method (Discounted Payback Period, Net Present Value, Profitability Index and Internal Rate of Return). The financial manager's aim is to get the most out of the firm's interest. A project's capital budgeting decision includes analyzing: the potential cash flows, and the level of uncertainty associated with these future project cash flows (Megginson \& Smart, 2009).

\subsection{Risk Measurement Methods}

Risk is explained as the probability of loss or a harmful effect that is associated with an action. It results from confusion. The greater the complexity, the greater the risk to an individual owner, the risk management means 
increasing expected returns that are subject to the risks involved (Crane et al, 2013). Risk is also a performance instability, which upsets the organization's goals (Crane et al, 2013). Many projects ' failure is either attributed to the simple fact that they have recently reported simple failures, or because the right problem has not been addressed (Crane et al, 2013). More significantly, the anticipated or future cash flows are a business estimate and not the real. Normally, the forecasts are based on assumptions that may be true or false. There is therefore a need for the company to embark on various evaluation analyzes of its expectations in order to obtain the best intellect of the overall risk of the project identified. For this study, literature is analyzed using three risk-measurement approaches.

\section{Research Methodology}

The research adopts a methodologically mixed approach involving both primary and secondary data. Here, in the midst of a well-structured questionnaire, multiple tools are used to objectively scrutinize the data and assess the impact of capital budgeting on National Investment Bank Ltd's management investment decision taking. The standardized questionnaires were developed to collect data from the company management. The questionnaires were designed to cover the goals of the study and resolve the research questions of the study as well. Considering the secondary data, with the use of content analysis, current reports are further analyzed. The productivity, corporate value and growth rate of the companies used as variables for data analysis controlled through data analytical tools such as Microsoft Office Excel, E-Views and statistical tables to systematically analyze the data collected and assess the study to examine the capital budgeting as a decision-making method for National Investment Bank Ltd.

\section{Data Analysis, Results and Discussions}

Using E-views, the data generated on the various variables under study have been analysed. The numerous data collected were performed on both descriptive and inferential statistics. The study's descriptive statistics consist of the measurement of central (mean) tendencies and dispersion measures (standard deviations). The inferential statistics discusses the regression analysis. The mean is best defined as the average value derived by dividing the total value of items by the number of items (Kothari, 2004). Standard deviation also measures the variation from the mean or the variability of the sample data (Mpunwa, 2013). It shows how the data deviate from the central tendency. Using structured questionnaires, the capital budgeting appraisal techniques mostly used by management are listed in order of preference thus Net present value, Internal rate of returns, Profitability index, Equivalent annuity, Payback period, Discounted payback and Real option analysis, Accounting rate of returns. The data contained in Table 1 below is generated from the National Investment Bank Ltd. Financial Statement (2006 - 2015) and used for the years under study to conduct the analysis for the various variables.

\subsection{Data analysis}

Using E-views, the data generated on the different variables under study were analyzed. The various data collected were performed on both descriptive and inferential statistics. The study's descriptive statistics consist of the calculation of core (mean) trends and dispersion measurements (standard deviations). The inferential statistics discusses the regression analysis.

The mean is best defined as the average value derived by dividing the total value of items by the number of items (Kothari, 2004). Standard deviation also measures the variation from the mean or the variability of the sample data (Mpunwa, 2013). Thus it shows how the data deviate from the central tendency.

\subsection{Data for the analysis}

Using structured questionnaires, the capital budgeting appraisal techniques mostly used by management are listed in order of preference thus; Net present value, Internal rate of returns, Profitability index, Equivalent annuity, Payback period, Discounted payback, Real option analysis and Accounting rate of returns

The data contained in table 1 below was generated from the financial statement of National Investment Bank Ltd. (2006 - 2015) and was used to run the analysis for the various variables for the years. 
Table 4.1: Net profit, Shareholders funds, Assets Value and Growth rate figures (2006 - 2015).

\begin{tabular}{|l|l|l|l|c|}
\hline & Net profit & Shareholders' funds & & Growth rate \\
Years & $(\mathrm{Gh} \phi)$ & $(\mathrm{Gh} \phi)$ & Assets value $(\mathrm{Gh} \phi)$ & $(\mathrm{Gh} \phi)$ \\
\hline 2006 & 4,427 & 39,240 & 279,798 & 0.1350 \\
\hline 2007 & 5,989 & 43,498 & 344,255 & 0.2304 \\
\hline 2008 & $-28,574$ & 33,551 & 410,758 & 0.1932 \\
\hline 2009 & $-23,113$ & 60,555 & 543,652 & 0.3235 \\
\hline 2010 & 2,424 & 66,093 & 721,137 & 0.3265 \\
\hline 2011 & 7,587 & 84,065 & 880,317 & 0.2207 \\
\hline 2012 & 11,637 & 100,210 & 876,939 & $(0.0038)$ \\
\hline 2013 & 38,528 & 285,397 & $1,189,951$ & 0.3569 \\
\hline 2014 & 79,396 & 486,824 & $2,319,574$ & 0.9493 \\
\hline 2015 & 120,107 & 543,180 & $2,654,693$ & 0.1445 \\
\hline
\end{tabular}

Source: NIB financial statement 2006-2015

Table 4.2: Descriptive Statistics

\begin{tabular}{|l|l|l|l|}
\hline & Net Profit & Growth Rate & Firm's Value \\
\hline Mean & 21840.80 & 0.287620 & 174261.3 \\
\hline Median & 6788.000 & 0.225550 & 75079.00 \\
\hline Maximum & 120107.0 & 0.949300 & 543180.0 \\
\hline Minimum & -28574.00 & -0.003800 & 33551.00 \\
\hline Std. Dev. & 46005.59 & 0.256209 & 194229.3 \\
\hline Skewness & 1.088156 & 1.793690 & 1.131041 \\
\hline Kurtosis & 3.174509 & 5.730104 & 2.570973 \\
\hline & & & \\
\hline Jarque-Bera & 1.986162 & 8.467819 & 2.208784 \\
\hline Probability & 0.370434 & 0.014496 & 0.331412 \\
\hline & & & \\
\hline Sum & 218408.0 & 2.876200 & 1742613. \\
\hline Sum Sq. Dev. & $1.90 \mathrm{E}+10$ & 0.590789 & $3.40 \mathrm{E}+11$ \\
\hline & & & 10 \\
\hline Observations & 10 & 10 & \\
\hline
\end{tabular}

Source: E-views

Table 4.2 above describes the descriptive statistics derived from the variables.

Figure 4.1: The trend of shareholders' funds for the period 2006-2015.

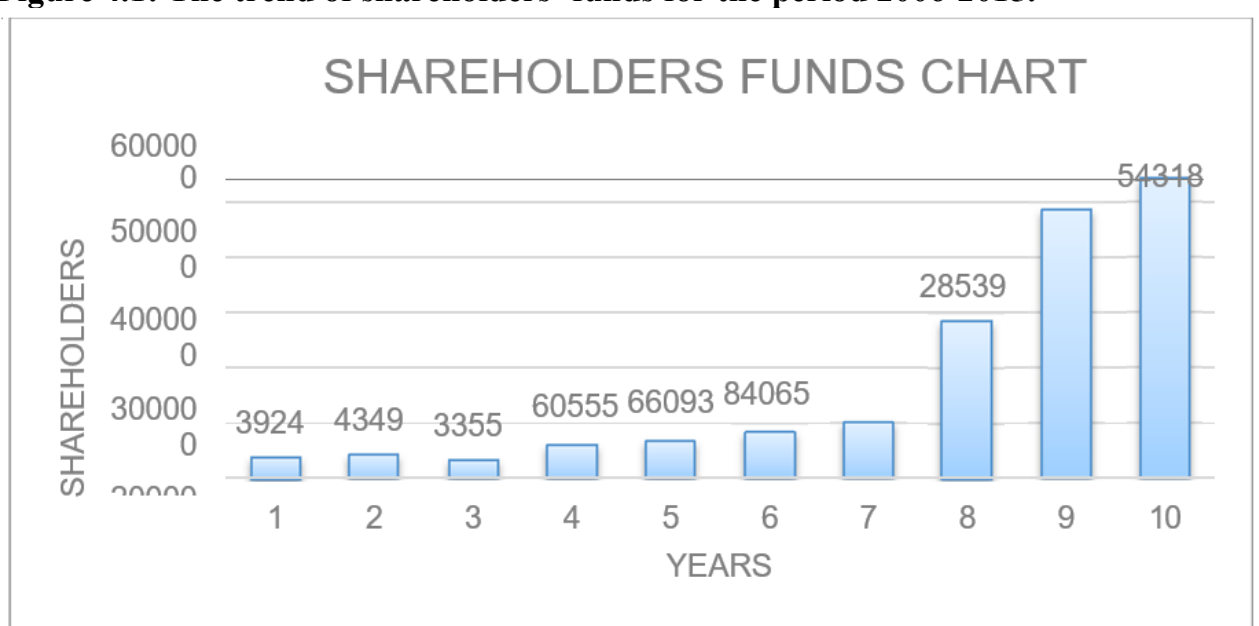

Source: Authors' construction based on NIB annual reports (2006-2015)

Figure 4.1 above shows shareholders fund for the period 2006 - 2015. It was identified that, the least shareholders fund was recorded in the year 2008 with an amount of GH $\varnothing 33,551.00$. The highest amount recorded was $\mathrm{GH} \notin 543,180.00$ and this was in the year 2015. 
Figure 4.2: Trend of growth rate for the period 2006-2015

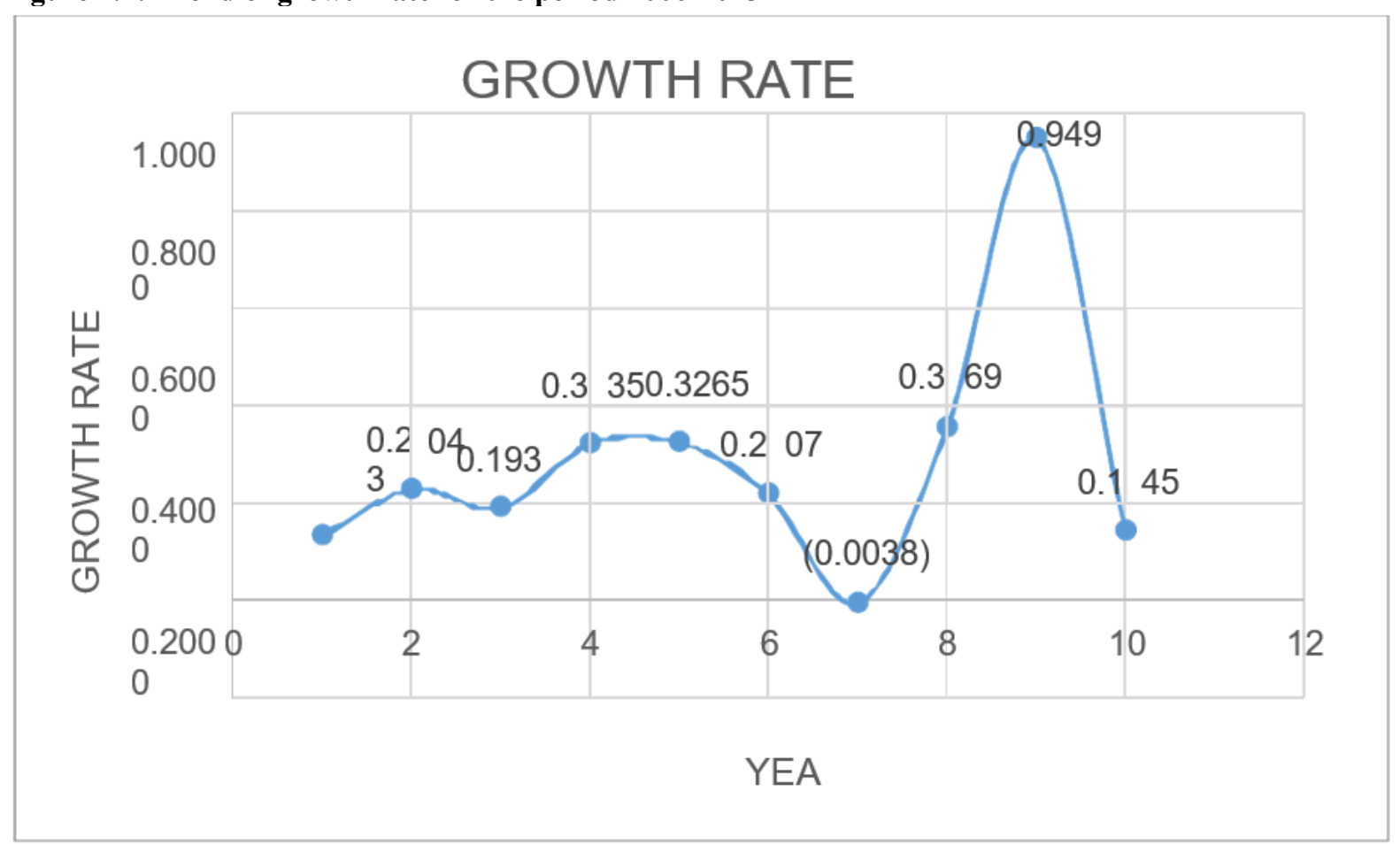

Source: Authors' construction based on NIB annual reports (2006- 2015)

Figure 4.2 above shows the growth rate of NIB Ltd for the period 2006 to 2015 . The growth rate is the amount by which the asset value increases over a specified period as a percentage of its previous value. Thus, changes in asset value divided by the previous year is shown in the chart above. It could be depicted from the chart that, the growth rate of NIB for the years under consideration (2006-2015) is not steady. It increases over time, decreases, increases and again decreases.

From Figure 4.2, it shows that the first two years (2006 and 2008) shows an increase in growth rate from 0.1350 to 0.2304 and decreases to 0.1932 . Then again, a further increase in the growth rate from 0.1932 to 0.3265 for the next two years $(2008-2010)$. From the period $(2010-2012)$ the growth rate decreases for that period and again increases to 0.9493 as the maximum growth rate recorded for the period under consideration. Finally, the growth rate declined from 0.9493 to 0.1445 for the last year $(2014-2015)$.

Figure 4.3: Trend of profitability for the period 2006-2015

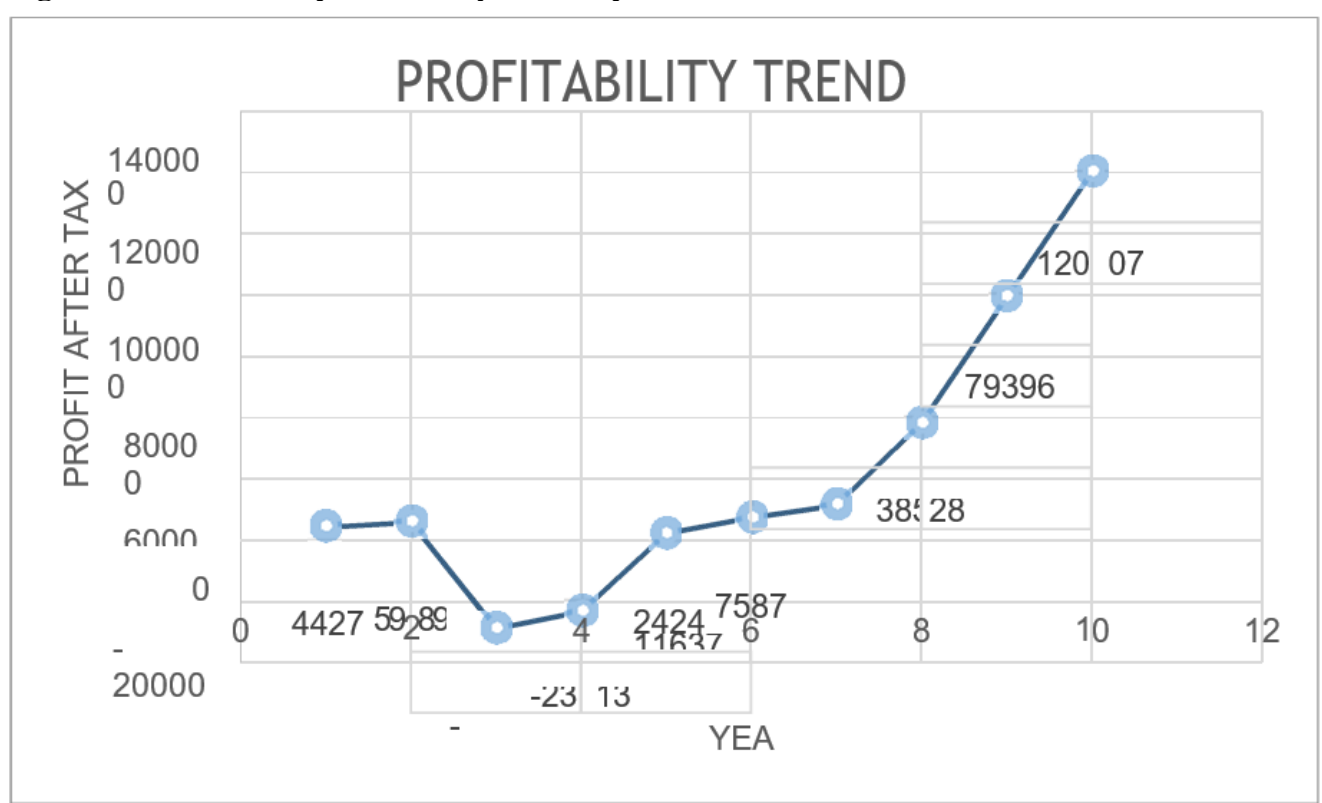

Source: Authors' construction based on NIB annual reports (2006- 2015) 
A profitability trend shows how profit has evolved over the years from 2006-2015 within the business. An upward movement or trend depicts an increase in profit whiles a downward movement depicts a declining profit over time in the short or long run. This trend mostly helps management to recognize problems in profitability and best able to address revenue and cost issues (Kokemuller, 2017).

The figure above (Figure 4.3), depict the trend at which profitability increase or decreases for the period 2006 to 2015 at National Investment Bank Limited. It can be seen that from the first two years (2006 and 2007) profit increases by $\mathrm{GH} \phi 1,562.00$ and thereafter decreases to $(\mathrm{GH} \phi 28,574.00)$ and $(\mathrm{GH} \phi 23,113.00)$ respectively for the years 2008 to 2009 . However, the firm covered up the losses and increase profit for the subsequent years (20102015).

\subsection{Interpretation of analysis}

For effective interpretation of the analysis generated, descriptive statistics, covariance analysis and regression analysis were used.

\subsubsection{Description of range of data}

The maximum and minimum amount of net profit after tax for NIB for the period 2006 - 2015 are GH $\notin 120,107.00$ and $\mathrm{GH} \phi-28,574.00$ respectively. This shows that the least amount of profit after tax generated for the period is the minimum value whilst the highest amount of profit after tax generated is the maximum. The maximum growth rate for NIB is represented by $0.95 \%$ and the minimum as $-0.01 \%$, as depicted from the table above. Therefore profit after tax for NIB for the period under consideration falls within the minimum and maximum values. The firm's value as shown in the table also ranges from $\mathrm{GH} \varnothing 33,551.00$ to $\mathrm{GH} \varnothing 543,180.00$ respectively.

\subsubsection{Description of the center of the data}

From Table 2.0 above, GH $\not 21,840.80$ which represent the mean of the distribution explains that, on average comparing the net profits for the ten periods, National Investment Bank generates GH $\varnothing 21,840.80$ as their net profit for the year. With the FV, National Investment Bank increases the firm's value by GH $\phi 174,261.30$ averagely, which represent 0.287620 on average. This means that NIB on average grows their net profit by $29 \%$.

\subsubsection{Description of the spread of the data}

From Table 2.0 above, comparing the standard deviation which describes how spread out the data is from the mean. It could be read from the table that standard deviation of 46005.59 for net profit represent a wider spread of the data from its mean value thus a higher degree of variability. With the firm's value, it is also spread out from the data point with a standard deviation of 194229.3. Then finally the growth rate of NIB has a standard deviation of 0.256209 approximately $26 \%$ degree of dispersion from its mean. Empirical evidence is shown in table 2.0 above.

\subsubsection{Description of the spread and shape of the data}

Skewness explains the direction of variation of the data set. Skewness is a measure of symmetry, or more precisely, the lack of symmetry (Alagidede \& Muazu, 2016). Statistically, zero (0) represents symmetry, but from table 2.0 net profit, firms value and the growth rate of NIB are positively skewed which is represented by 1.088156 , 1.131041 and 1.793690 respectively. This means to be more elaborative, the shape of the graph is highly skewed to the right. The value of kurtosis and skewness shows a non-normal distribution of profit and growth rate suggesting that the distribution of net profit and growth rate is leptokurtic (Alagidede \& Muazu, 2016). Thus the distribution of growth rate and net profit is greater than three (3).

Test statistic for the normal distribution of series is the Jarque-Bera (Eviews, 2016). The difference between skewness and kurtosis of the series with those from the normal distribution is measured by this test statistics. Basically is computed as:

$$
\text { Jargue-Bera }=\frac{N}{6}\left(s^{2}+\frac{(K-3)^{2}}{4}\right.
$$

Where $\mathrm{S}$ is the skewness and $\mathrm{K}$ is the kurtosis. $\overline{6} \quad \frac{4}{4}$

Table 4.2 indicates a high J-B recorded was 1.986162, 8.467819 and 2.208784 representing net profit, growth rate and firms value respectively. Sum square in the table recorded from the table were 1.90E+10, 0.590789 and $3.40 \mathrm{E}+11$ representing net profit, growth rate and firms value respectively. This helps to evaluate the disparity from the mean. The estimation of the total sum of squares reflects both the sum of squares from the factors and from randomness or error (Minitab, 2016). 


\subsubsection{Covariance Analysis: Ordinary}

Table 3.0: Ordinary covariance analysis Sample: 2006 - 2015

Included observations: 10

\begin{tabular}{|c|c|c|c|}
\hline \multicolumn{4}{|l|}{$\begin{array}{l}\text { Covariance } \\
\text { Correlation } \\
\text { t-Statistic }\end{array}$} \\
\hline Probability & PR & GR & FV \\
\hline \multirow[t]{3}{*}{ PR } & $1.90 \mathrm{E}+09$ & & \\
\hline & 1.000000 & & \\
\hline & $-\cdots$ & & \\
\hline \multirow[t]{4}{*}{ GR } & 3505.984 & 0.059079 & \\
\hline & 0.330493 & 1.000000 & \\
\hline & 0.990429 & ---- & \\
\hline & 0.3510 & ---- & \\
\hline \multirow[t]{4}{*}{ FV } & $7.69 \mathrm{E}+09$ & 22242.20 & $3.40 \mathrm{E}+10$ \\
\hline & 0.955816 & 0.496622 & 1.000000 \\
\hline & 9.196508 & 1.618331 & ---- \\
\hline & 0.0000 & 0.1443 & ---- \\
\hline
\end{tabular}

The table 4.3 above illustrates the covariance, correlation, t-statistics and probability that were generated with the use of E-Views from the data generated from the financial statement. This explains the correlation coefficient of firm's value, net profit and growth rate. Much attention is on the correlation between firm's value and growth rate then also the correlation between firm's value and net profit.

Pearson method was used to determine the degree of correlation between these variables and this is as follows:

$$
r=\frac{n \sum X Y-\sum X \sum Y}{\sqrt{\left(n \sum X^{2}-\left(\sum X\right)^{2}\left(\sum Y^{2}-\left(\sum Y\right)^{2}\right.\right.}}
$$

From the formula, $\mathrm{X}$ and $\mathrm{Y}$ represents pairs of data for two variables $\mathrm{X}$ and $\mathrm{Y} . \mathrm{n}=$ the number of pairs of data used in the analysis. In our study $n=10$. The coefficient ranges from -1 and +1 . Where $r=+1$, it signifies that the variables are perfectly positively correlated. Where -1 represents that the variables are perfectly negatively correlated. Then again where $r=0$, it means the variable are linear and thus uncorrelated (Salkind, 2013).

Our results suggest that, net profit and growth rate are positively correlated with firm's value. From the table correlation coefficient of 0.955816 represents positively strong form correlation which represents the correlation coefficient of firm's value and profitability. Then again 0.496622 correlation coefficient between firms value and growth rate depicts positively weak form correlation.

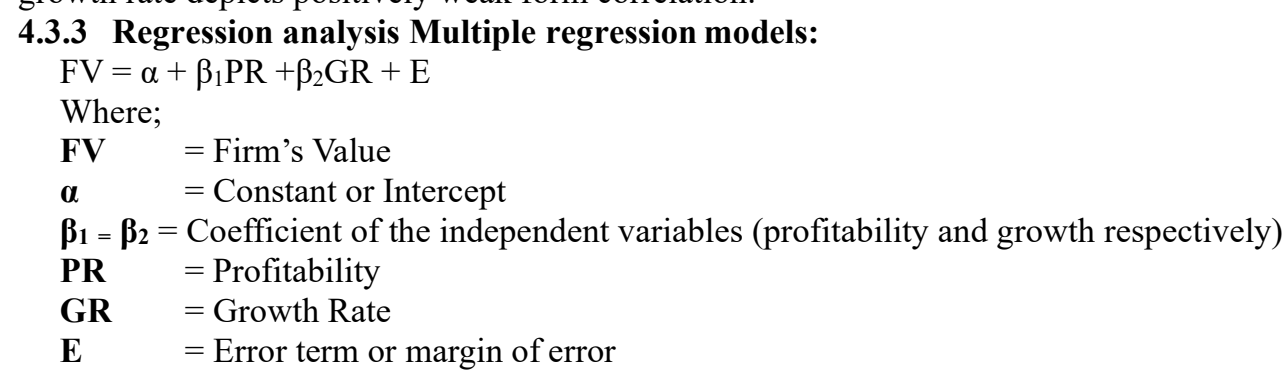


Table 4.0 Regression Analysis

Dependent Variable: FV Method: Least Squares

Date: 28/12/19 Time: 12:20

Sample: 2006 - 2015

Included observations: 10

\begin{tabular}{lllll}
\hline \hline Variable & Coefficient & Std. Error & t-Statistic & Prob. \\
\hline C & 48070.65 & 24132.84 & 1.991918 & 0.0866 \\
PR & 3.752230 & 0.377097 & 9.950295 & 0.0000 \\
GR & 153810.4 & 67712.57 & 2.271519 & 0.0573 \\
\hline R-squared & 0.950253 & & & \\
Adjusted R-squared & 0.936040 & & & \\
S.E. of regression & 49121.23 & & & \\
F-statistic & 66.85641 & & & \\
Prob(F-statistic) & 0.000027 & & & \\
\hline
\end{tabular}

The coefficient of determination $\left(\mathrm{R}^{2}\right)$ of 0.950253 indicates that about $95 \%$ of the variation or changes in the dependent variable (firm's value) is due to the variation or changes in the independent variables (profit and growth rate). The adjusted $\mathrm{R}^{2}$ also shows that after controlling the number of independent variables affecting the firm's value, 94\% approximately of the variation in firm's value is caused by the profit and the growth rate of the firm. The overall model significance is checked relying on the prob (F-statistics) of 0.000027 which shows

the variables are jointly significant at $1 \%$. The results generated from the E views, the coefficient of the independent variables shows that profit and growth rate positively affects firms value and their effect are significant at $1 \%$ and $10 \%$ respectively. The positive relationship and significance shows that an increase in the profitability and growth rate also increases firm's value.

\subsection{Discussion of Analysis}

In examining the data generated from the financial statements, it can be seen that the profitability, growth rate and firms value are directly related. Thus, as profit increases, growth rate increases and the overall objective (firm's value) also increases. In the descriptive analysis, on average the firms value is GHф174,261.3 which is somehow good for investment.

From the correlation analysis generated, there exists a positive relationship between the variables considered under the study. With $0.330493,0.955816$ and 0.496622 being the correlation coefficient between growth rate and profit, firms value and profit and growth rate and firms value. This shows that an increase/decrease in growth rate and profit will lead to an increase/decrease in the firm's value which is the ultimate goal of the firm.

The regression analysis supported the argument made in the correlation analysis that profit and growth rate affect the firm's value and their effect are significant at $1 \%$ and $10 \%$ respectively. Also the $\mathrm{R}^{2}$ and the Adjusted $\mathrm{R}^{2}$ of 0.950253 and 0.936040 shows that the model is adequate since the most important variables were captured in the model. With the joint significance of the model, the Pro (F-statistics) of 0.000027 depict that the overall model is significant at $1 \%$ level of significance.

\section{Conclusion and Recommendations}

The general objective of the study is to examine the capital budgeting tools used by National Investment Bank and how the use of such tools impact on the firms value, profit and growth rate. It was revealed that capital budgeting has a great positive impact on the organization's performance in terms of profitability, growth and firms value and also gives strategic direction and focus. The findings of the research show that in appraising of investment projects, National Investment Bank uses capital budgeting tools such as Net Present Value, Internal Rate of Return, and Profitability index, Payback Period, Accounting Rate of Return, among others in order of preference. The use of these tools is meant to maximize the firm's value which is affected by the firm's profit and growth rate. However, not limited to only the financial factors such as profit and growth rate that affect the firms value, inflation and other non-financial factors including legal requirement, matching industry standards, consultation of key players, improving business reputations and anticipating all dealings threats also hinders the viability of a project to maximize the firms value.

The correlation analysis and regression analysis results shows that there is a positive relationship between the capital budgeting tools proxied as firms value and the profit and the growth rate of the firm and also establish a significant relationship at $1 \%$ level of significance. The coefficient of determination from the regression analysis also shows that the model is adequate where about $96 \%$ of the variation in the firm's value was explained by the profit and the growth rate of the firm with the reminder caused by the other non-financial factors. This shows the strength of the relationship that exists between the firm's value and independent variables, profit and growth rate and how adequate the model is.

Considering the findings and the conclusion, the study recommends, first that capital budgeting being an 
important tool for decision making with a positive impact on the organization's performance in terms of profitability, growth and firm's value and also gives strategic direction and focus, must be considered seriously. There is the need for urgent education and training of staff on the various capital budgeting tools and the formation of knowledgeable team that will evaluate project using the capital budgeting tools due to its irreversibility nature, huge initial investment outlay and its long term effect. Secondly, the cost of capital and the rate of returns of the firm should always be inflationary adjusted. Management of firms should always take into consideration the inflation rate of the economy before choosing the required rate of return and the cost of capital. Due to time value of money, it is appropriate to use real rate of returns that considers the rate of inflation of the economy that will help make the estimates more accurate. Furthermore, Investment Banks must be abreast with the Central Bank and other legal regulations in their investment appraisal techniques. Then also, management must also take into account taxation and other governmental policies on capital budgeting. Thus firms must prepare their capital budgeting techniques in line with the legal requirement as stated in the Companies code 1963 act, 179 to help keep the business in session for effective running and operations. Therefore current rates as stated by the regulatory bodies must be as early as possible to be able to make accurate estimations. In addition, firms must also practice capital rationing. Due to restricted capital, the firm must not keep idle funds due to time value of money. Some investment might not generate the highest returns but the one with the highest return may require higher investment outlay and due to restricted capital the investment could be considered viable while underscoring that researchers should take our findings into consideration and also consider the impact of non-financial factors that affect capital budgeting as well as the effects of technological advancement on capital budgeting in investment companies.

\section{References}

Baker, K. H., \& English, P. (2011). Capital Budgeting Valuation: Financial Analysis for Today's Investment Projects. Canada: John Wiley and Sons, Inc.

Crane, L., Gantz, G., Isaacs, S., Jose, D., \& Shar, R. (2013). Introduction to risk management. Understanding agricultural risk Extension risk management education and risk management agency.

Dayananda, D., Iron, R., Harrison, S., Berbohnjohn, \& Roland, P. (2002). Capital Budgeting: Financial Appraisal of Investment Projects. Uk: The Press Syndicate Of The University Of Cambridge.

Jones, T. (2002). Business Economics \& Managerial Decision Making. Canada: Wiley and Sons Inc.

Kokemuller, N. (2017). Small business. Profitability trend.

Kothari, C. R. (2004). Research Methodology: methods and techniques. (Second Revised Edition). Canada: New Age International (P) Limited, Publishers.

Mausu, I., \& Alagidede, P. (2016). Causes and effect of exchange rate volatility on economic growth, evidence from ghana.

Megginson, W. L., \& Smart, S. B. (2009). Introduction to Corporate Finance. USA: South- Western Cengage Learning.

Minitab Inc. (2016). Retrieved from Http://Support.Minitab.Com/En-Us/Minitab/17/Topic- Library/Modeling Statistics/Anova/Anova-Statistics/Understanding-Sums-Of-Squares/.

Mpunwa, D. (2013). Statistics for Business. Windhoek: Business School.

Munyao, A. (2010). The Relationship Between Capital Budgeting Techniques And Financial Performance Of Companies Listed At The NSE. University Of Nairobi.

Nyambura, I. E. (2014). The Relationship Between Capital Budgeting Techniques And Financial Performance Of Companies Listed On The Nairobi Security Exchange.

Peavler, R. (2017). Cash flow analysis, techniques and tips. Business finance.

Peterson, P. P., \& Fabozzi, F. J. (2002). Capital Budgeting: Theory and Practice. Canada: John Wiley and Sons, Inc.

Salkind, N. (2013). Exploring Research. Johannesburg: Pearson Publishers.

Uwah, U. E., \& Asuquo, A. I. (2016). Capital budgeting processes and wealth maximization objectives: implication for firms in Nigeria. Research journal of finance and accounting, vol. 7, No. 10. 